\title{
鼻・副鼻腔原発悪性リンパ腫16症例の検討
}

$\begin{array}{lrrr}\text { 永澤 } & \text { 昌・夜陣 } & \text { 紘治・西田 功 } \\ \text { 浜村 宣宏・有重 } & \text { 秀三・原田 康夫 } \\ \text { 難波 紘二* } & & & \end{array}$

\section{Primary Lymphomas of the Nasal Cavity and Paranasal Sinuses; A Clinico-Pathological Study of 16 Cases}

\author{
Akira Nagasawa, Koji Yajin, Isao Nishida, \\ Nobuhiro Hamamura, Shuso Arishige and Yasuo Harada \\ (Hiroshima University) \\ Koji Nanba \\ (Kure Kyosai Hospital)
}

\begin{abstract}
Sixteen patients with extranodal lymphoma originating in the nasal and/or paranasal cavity were initially treated between 1975 and 1988 and have been followed for more than 12 months. In 11 patients the lymphoma was stage I, in 4 stage II and in one stage III. The majority were classified pathologically as T-cell types $(81.2 \%)$ and high-grade lymphomas $(68.8 \%)$ according to the Working Formulation. Three patients were treated with radiotherapy alone, and 8 received a combination of chemotherapy (VEMP or VEPA) and radiation. Two others were treated with chemotherapy alone. Local control by the initial treatment was fairly good. Eleven patients achieved a complete response $(69 \%)$. The other 5 patients had high grade lymphomas with $\mathrm{T}$-cell surface markers and showed a poor response. The 3-year survival rate of 9 patients with the tumor confined to the nasal cavity was $75 \%$. The other 7 patients had involvement of the paranasal sinuses and failed to survive for 3 years. The overall 3-year survival rate was $45 \%$. The ralatively low survival rate may be due to poor control of distant metastases. Better results might be achieved by more intense initial chemotherapy, such as MACOP-B or CHOP-B.
\end{abstract}

Key words : malignant lymphoma, extranodal lymphoma, nasal cavity, paranasal sinus

はじめに

悪性リンパ腫（以下, ML) は，部断治療技術 の進歩，特に化学療法の進歩により，その治療 効果は年々上昇している.
当科の統計によると ${ }^{1)}$, 節外性 ML は, 非ホ ジキン ML の36. 5\%を占めるが, そのなかの比 較的多くが鼻・副鼻腔に原発している（節外性 MLの内の $68.4 \%$, 非ホジキン MLの内の 
24. $6 \%$ を占める). 年々, 治療成績が上昇して いる MLのなかにあって, 節外性 ML の予後 (3,5,7生率) は, ワルダイエル原発 ML と比較し ても，いずれも有意 $(\mathrm{p}<0.01)$ に不良であり（図 $\left.1^{11}\right)$ ，その大きな要因は鼻・副鼻腔原発 MLの 予後不良によっている.

本稿では，1975年から1988年までの間に，広 島大学医学部耳鼻咽喉科において, 初回治療を 行なった鼻・副鼻腔原発 ML 16 症例について 検討を加え, 今後の鼻・副鼻腔原発 ML の治 療の考え方について考案を行なった.

\section{対象と方法}

1975年より1988年の14年間に, 広島大学医学 部付属病院耳鼻咽喉科飞て初回治療を行ない, 初回治療後 1 年以上の観察を終えている, 鼻・ 副鼻腔原発 ML16 症例について検討を行なっ た. MLの病理組織学的診断は, review 組織診 断によって確定診断を行ない, 病理組織学的分 類には国際分類と LSG 分類を用い, 細胞マカーの検索屯行なった. フォルマリン固定, パ ラフィン包埋ブロックより, リンパ腫細胞表面 マーカー検索が可能なモノクローナル抗体とし て, UCHL-1，MT-1，L-26 を用いた2).すなわ ち， $\mathrm{T}$ 細胞の検索には前 2 者を， $\mathrm{B}$ 細胞の検索
には L-26 をその指標とし， 3 者の組み合わせ にて総合的に膜表面形質を決定した。 さらに， 疫学的因子, 病理組織学的分類, 治療方法と予 後との関連性を検討した.

\section{結 果}

16症例の内容を，表 1 に示した. 以下に，内 訳を述べる。

1 ）年齢・性分布（表 2)

性別では，男性が10例，女性が 6 例と男性に 多く，年齢分布は50歳代以上に多いが，同時期 に当科で経験した非ホジキン ML 全体での傾向 と同様に，30歳代にも一つのピークを示し，平 均年齢は55.9歳であった。

2 ) 臨床病期 (表 3 )

諸家の報告之同様( (3) 5) $^{3}$, 早期（I， 【 期）症 例が多かった（I：II：III=11:4:1).

3 ) 組織型分類 (表 4 )

組織型分類（国際分類）では，immunoblastic type が最も多く11例（68.8\%）であった. その なかでも $\mathrm{T}$ 細胞型が 8 例と多く，また他の組織 型 (diffuse small cleaved cell 2 例, mixed small and large cell 3 例) はいずれも $\mathrm{T}$ 細胞型であっ た $(\mathrm{T}: \mathrm{B}=13: 3)$. 悪性度別では, 中等度悪性群 5 例, 高度悪性群11例と高度悪性群が多かった。

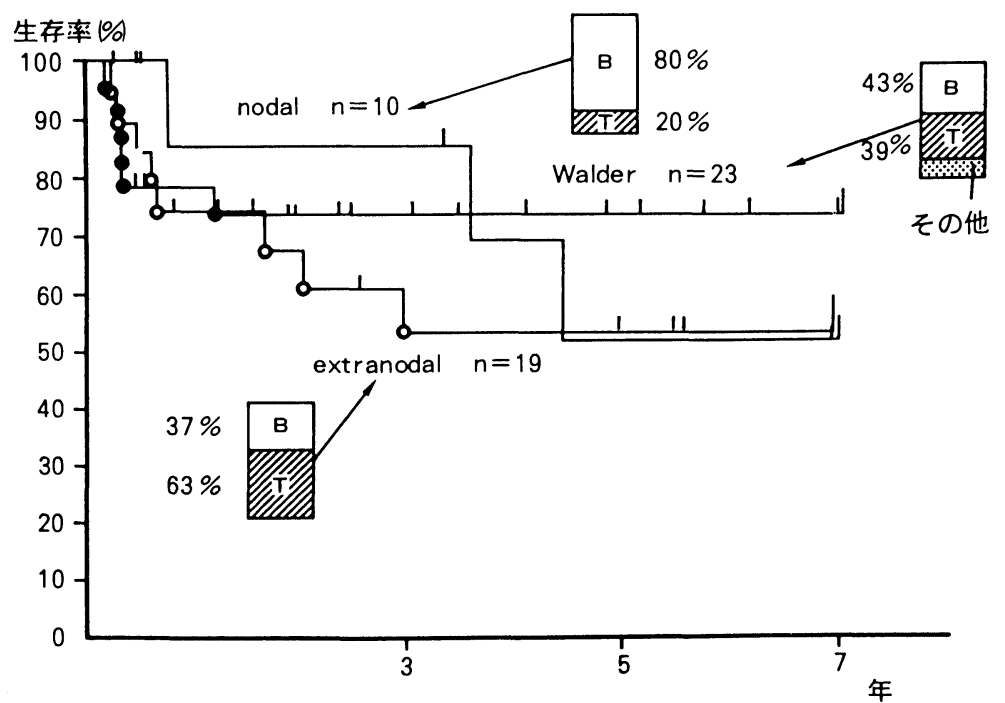

図 1 非ホジキンリンパ腫の生存曲線（河野嘉彦，他：1988 ${ }^{1)}$ より転載） 
表 1 鼻副鼻腔原発悪性リンパ腫症例

（1975～1988年, 広島大学医学部付属病院耳鼻咽喉科）

\begin{tabular}{|c|c|c|c|c|c|c|c|c|c|c|}
\hline \multirow{2}{*}{$\begin{array}{l}\text { 症 } \\
\text { 例 }\end{array}$} & \multirow{2}{*}{$\begin{array}{l}\text { 初 } \\
\text { 䛒 } \\
\text { 年 }\end{array}$} & \multirow{2}{*}{$\begin{array}{l}\text { 年 } \\
\text { 齡 }\end{array}$} & \multirow[b]{2}{*}{ 性 } & \multirow{2}{*}{$\begin{array}{l}\text { 病 } \\
\text { 期 }\end{array}$} & \multirow{2}{*}{\multicolumn{2}{|c|}{$\begin{array}{c}\text { 組 織 型 } \\
\text { 上段：国際分類 } \\
\text { 下段：LS G 分類 }\end{array}$}} & \multicolumn{2}{|c|}{ 初期治療 } & \multirow{2}{*}{$\begin{array}{l}\text { 再 発 有 無 } \\
\text { 再発時治療 }\end{array}$} & \multirow[b]{2}{*}{ 転 } \\
\hline & & & & & & & $\begin{array}{l}\mathbf{R} \\
T\end{array}$ & 化学療法 & & \\
\hline 1 & 1975 & 71 & 男 & $\mathrm{I}_{\mathrm{A}}$ & $\begin{array}{l}\text { IBL } \\
\langle\mathrm{D}-\mathrm{Mix}\rangle\end{array}$ & (B) & + & VEP & +1977局所 & $\begin{array}{l}\text { 他病死 }(1 \text { 年11月 }) \\
\text { 直腸 } \mathrm{Ca} .\end{array}$ \\
\hline 2 & 1976 & 25 & 男 & $\mathrm{II}_{A}$ & $\begin{array}{l}\text { DML } \\
\langle D-M i x\rangle\end{array}$ & (T) & + & 転 科 & （CRに至らず） & $\begin{array}{l}\text { 死亡( } 1 \text { 年 } 5 \text { 月) } \\
\text { 全身転移 }\end{array}$ \\
\hline $\begin{array}{c}3 \\
\star\end{array}$ & 1977 & 51 & 男 & $I_{B}$ & $\begin{array}{l}\text { DML } \\
\langle D-M i x\rangle\end{array}$ & ( $T$ ) & + & - & $\begin{array}{l}+1984 \text { 局所 } \\
\text { RT、VEMP }\end{array}$ & $\begin{array}{l}\text { 死亡(8年) } \\
\text { 肝転移 } \Rightarrow D I C\end{array}$ \\
\hline 4 & 1978 & 56 & 女 & $I_{B}$ & $\begin{array}{l}\mid \mathrm{IBL} \text {, clear } \\
\langle\mathrm{D} \text {-Large }\rangle\end{array}$ & ( $T$ ) & + & VEMP & （C Rに至らず） & $\begin{array}{l}\text { 死亡(3力月) } \\
\text { 肝転移、腹獏炎 } \Rightarrow \text { 消化管出血 }\end{array}$ \\
\hline $\begin{array}{r}5 \\
\star \\
\end{array}$ & 1979 & 37 & 男 & $\mathrm{II}_{A}$ & $\begin{array}{l}\text { IBL, clear } \\
\langle\mathrm{D}-\mathrm{Mix}\rangle\end{array}$ & $(T)$ & + & - & $\begin{array}{l}+1984 \text { 上頜 } \\
\text { RT、VEPA }\end{array}$ & 生存 ( 9 年) \\
\hline $\begin{array}{l}6 \\
\star\end{array}$ & 1979 & 77 & 男 & $I_{A}$ & $\begin{array}{l}\mathrm{IBL} \\
\langle\mathrm{D} \text {-Large }\rangle\end{array}$ & (B) & + & VEMP & - & 生存( 9 年) \\
\hline $\begin{array}{l}7 \\
\star\end{array}$ & 1979 & 65 & 男 & $I_{A}$ & $\begin{array}{l}\text { IBL, clear } \\
\langle\mathrm{D}-\mathrm{Mix}\rangle\end{array}$ & ( $T$ ) & + & VEMP & - & $\begin{array}{l}\text { 死亡(6 カ月) } \\
\text { 出血性膀胱炎 } \Rightarrow D I C\end{array}$ \\
\hline $\begin{array}{l}8 \\
\star \\
\end{array}$ & 1980 & 75 & 男 & $I_{A}$ & $\begin{array}{l}\text { DML } \\
\langle D-M i x\rangle\end{array}$ & ( $(\mathrm{T})$ & - & VEMP & - & 生存 (8年) \\
\hline $\begin{array}{l}9 \\
\star\end{array}$ & 1981 & 64 & 女 & $\mathrm{II}_{\mathrm{A}}$ & $\begin{array}{l}\mathrm{IBL} \\
\langle\mathrm{D} \text {-Large }\rangle\end{array}$ & ( $(T)$ & + & VEM & - & 生存（7年） \\
\hline $\begin{array}{l}10 \\
\star\end{array}$ & 1982 & 33 & 男 & $\mathrm{II}_{A}$ & $\begin{array}{l}\text { IBL, clear } \\
\langle\mathrm{D}-\mathrm{Mix}\rangle\end{array}$ & $(T)$ & - & VEPA & - & 生存 (6年) \\
\hline 11 & 1982 & 34 & 女 & III & $\begin{array}{l}\mid \mathrm{BL} \\
\langle\mathrm{D} \text {-Large }\rangle\end{array}$ & ( $(T)$ & + & VEPA & （C Rに至らず） & 死亡 (2力月) \\
\hline 12 & 1983 & 80 & 男 & $I_{A}$ & $\begin{array}{l}\text { DSCL } \\
\langle\mathrm{D}-\mathrm{Med}\rangle\end{array}$ & ( $(T)$ & + & - & - & $\begin{array}{l}\text { 他病死 ( } 1 \text { 年 } 2 \text { 月) } \\
\text { 脳血栓 }\end{array}$ \\
\hline 13 & 1983 & 72 & 女 & $\mathrm{I}_{\mathrm{A}}$ & $\begin{array}{l}\mid \mathrm{BL} \\
\langle\mathrm{D} \text {-Large }\rangle\end{array}$ & (B) & + & - & $\begin{array}{l}+1983 \text { 局所 } \\
\text { RT範囲外 }\end{array}$ & $\begin{array}{l}\text { 死亡(11力月) } \\
\text { 全身転移 }\end{array}$ \\
\hline 14 & 1984 & 46 & 女 & $\mathrm{I}_{\mathrm{A}}$ & $\begin{array}{l}\text { DSCL } \\
\langle\text { D-Med }\rangle\end{array}$ & ( $(T)$ & + & VEMP & $\begin{array}{l}+1986 \\
\text { 全身転移 }\end{array}$ & $\begin{array}{l}\text { 死亡(2年5月) } \\
\text { 肺真菌症、DIC }\end{array}$ \\
\hline $\begin{array}{l}15 \\
\star \\
\end{array}$ & 1986 & 50 & 男 & $I_{A}$ & $\begin{array}{l}\mid \mathrm{IBL} \\
\langle\mathrm{D} \text {-Large }\rangle\end{array}$ & ( $(T)$ & - & VEPA & $\begin{array}{l}\text { +、1986局所 } \\
\text { RT、VEPA、他 }\end{array}$ & $\begin{array}{l}\text { 生存(2年 3月) } \\
\text { 局所に腫凝あり }\end{array}$ \\
\hline $\begin{array}{c}16 \\
\star\end{array}$ & 1987 & 57 & 女 & $I_{A}$ & $\begin{array}{l}\text { IBL } \\
\langle\mathrm{D} \text {-Large }\rangle\end{array}$ & ( $(T)$ & + & VEPA & （CRに至らず） & $\begin{array}{l}\text { 死亡(3 カ月) } \\
\text { 頭蓋内漫潤 } \Rightarrow \text { 呼吸不全 }\end{array}$ \\
\hline
\end{tabular}


当科で経験した非ホジキン ML 全体では, 中等 度悪性群が多い(59.6\%)のに比較し, 対照的か つ特徵的な結果であった。

\section{4 ）初回治療効果（寛解率）}

治療効果の判定は, NCI (1976) の判定基準に 従った（表 5 ). 16症例中, 完全寛解が11例, 部 分寛解が 1 例(表 1 の症例 2 )，無効が 4 例であ り，比較的局所制御が良い結果を得た。しかし， 早期でありながら，治療に反応が悪く急激な転 帰で死亡する治療抵抗例が 3 例（表 1 の症例 4, 11，16）あり，いずれあ $\mathrm{T}$ 細胞型であった.

また, 完全寛解後の再発例 4 例について検討 したところ，放射線照射範囲外の隣接領域での
局所再発が多く見られた(表 6$)$.

5 ) 生存率 (図 2)

予後に関しては，8 年後に局所再発および肝 転移をきたして死亡した 1 例（表 1 の症例 3 ） をのぞけば，再発（再燃）・転移をきたして死

表 3 臨床病期

\begin{tabular}{lccr}
\hline Clinical Stage & I & : & 1 \\
& II & 1 & 4 \\
& III $:$ & 1 \\
& IV & 0 \\
\hline
\end{tabular}

全身症状を伴う症例は、2例あつた。

いずれも、I $\mathrm{B}$ 期症例であった。

表 2 年齢・性分布

\begin{tabular}{|c|c|c|c|}
\hline 非ホジキンリンパ腫 & 年歯層 & \multicolumn{2}{|c|}{ 貫副重腔原発リンパ腫 } \\
\hline $4 \square \square \square \mathbf{\square}$ & $\sim 29$ & \\
\hline $7 \square 0 \mathbf{0 0 0}$ & $30 \sim 39$ & \multicolumn{2}{|l|}{$\mathbf{a} \square 3$} \\
\hline $4 \square \square \square \square$ & $40 \sim 49$ & \multicolumn{2}{|l|}{$\square 1$} \\
\hline 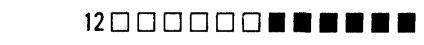 & $50 \sim 59$ & 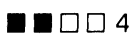 & ．电 \\
\hline 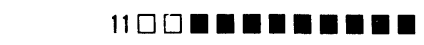 & $60 \sim 69$ & $\mathbf{\square} \square 2$ & $\square:$ 文 \\
\hline 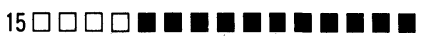 & $70 \sim 79$ & $\mathbf{E} \square 4$ & \\
\hline $2 \square \square$ & $80 \sim$ & \multicolumn{2}{|l|}{$\mathbf{\square} 1$} \\
\hline 55 (男：37、女：18) & 計 & \multicolumn{2}{|c|}{ 16 (男：10、女：6) } \\
\hline
\end{tabular}

表 4 組織型の内訳

\begin{tabular}{|c|c|c|c|}
\hline 悪性度群 & 組織型(国際分類) & 症例数 $(O=1$ 症例 $)$ & 群別例数 \\
\hline \multirow{3}{*}{ 軽度悪性 } & Small Lymphocytic & & \multirow{3}{*}{0} \\
\hline & Foll. Small Cleaved & & \\
\hline & Foll. Mixed & & \\
\hline \multirow{4}{*}{ 中等度悪性 } & Foll. Large cell & & \multirow{4}{*}{5} \\
\hline & Diff. Small Cleaved & 00 & \\
\hline & Diff. Mixed & 000 & \\
\hline & Diff. Large cell & & \\
\hline \multirow{4}{*}{ 高度悪性 } & Immunoblastic-T & 00 & \multirow{4}{*}{11} \\
\hline & Immunoblastic-B & 00 & \\
\hline & Lymphoblastic & & \\
\hline & Small Non-Cleaved & & \\
\hline 計 & & & 16 \\
\hline
\end{tabular}


亡する場合は最長 2 年 6 力月で，いずれも 3 年 以内であった。 このように，予後を悪化せしめ る要因と 3 年生存率 (以下, 3 生率) との関係 を検討したところ，3 生率と病巣の拡がりとの

表 5 治療効果判定基準

\begin{tabular}{|c|c|}
\hline \multicolumn{2}{|c|}{ 完全寛解 (CR)：臨床的に、すべての腫瘍消失が } \\
\hline & 3カ月以上持続した場合 \\
\hline \multicolumn{2}{|c|}{ 部分寛解 (PR)：腫瘍の $50 \%$ 以上の縮小効果が } \\
\hline & 3 カ月以上持続した場合 \\
\hline \multirow[t]{2}{*}{ 無 } & 効 (NR)：治療に全く反応しないか、縮小 \\
\hline & 効果が3カ月持続しない場合 \\
\hline
\end{tabular}

間にのみ有意の相関を認めた（表 $7, \mathrm{p}<0.01)$. つまり，病巣が鼻腔に限局する症例では，比較 的予後が良好 ( 3 生率=75.0\%)であったが，病 巣が副鼻腔におよぶ症例(副鼻腔原発症例, ない

表 6 完全寛解後の再発:4 例（重複あり）

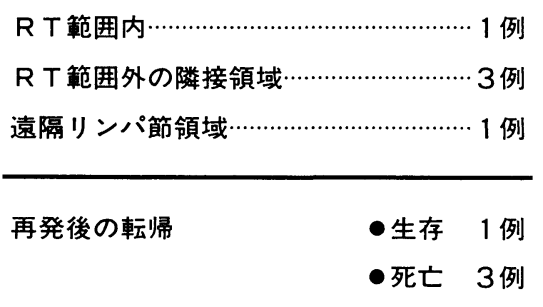

表 7 病巣の拡がりと 3 生率

\begin{tabular}{|c|c|c|c|c|}
\hline 初期治療 & $R T$ & RT + Chemo. & Chemotherapy & 3生率 \\
\hline 鼻 腔 限 局 & $\square \square$ & $\square \square \square \square$ & $\square \square$ & $6 / 8$ \\
\hline 副臬腔に及ぶ & $\square$ & $\mathbf{a}$ & & $0 / 5$ \\
\hline 計 & $2 / 3$ & $2 / 8$ & $2 / 2$ & $6 / 13$ \\
\hline
\end{tabular}

$\square: 3$ 年後生存 $\square: 3$ 年以内死亡

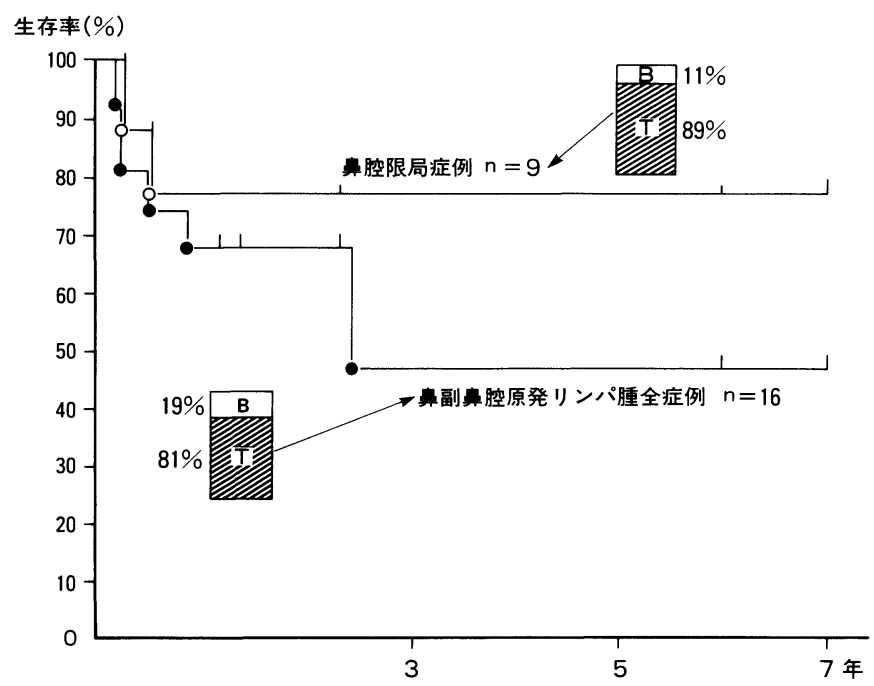

図 2 鼻・副鼻腔原発リンパ腫の生存曲線 
し鼻腔原発で副鼻腔への浸潤の存在する症例) の予後は極端に悪かった ( 3 生率=0\%). 組織 学的悪性度や細胞型 (表 8), 臨床病期 (表 9 ), 初回治療の内容 (表10) と予後とは, 有意な相関 を今回の検討では認めなかった。

\section{考案}

非ホジキン MLの分類は，日本では LSG 分 類，ヨーロッパではキール分類，米国では国際 分類 (Working Formulation; WF) が主に使用 され，長期間の症例検討においては, Rappaport

表 8 病理組織型と 3 生率

\begin{tabular}{|c|c|c|c|c|}
\hline 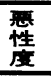 & 細胞 組 織 型 & T 細胞型 & B 細胞型 & 3生率 \\
\hline \multirow{2}{*}{$\begin{array}{l}\text { 中 } \\
\text { 等 } \\
\text { 度 }\end{array}$} & Diff. Small Cleaved & $\mathbf{\square}$ & & \multirow{2}{*}{$2 / 4$} \\
\hline & Diff. Mixed & "ם & & \\
\hline $\begin{array}{l}\text { 高 } \\
\text { 度 }\end{array}$ & Immmunoblastic & 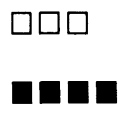 & $\begin{array}{l}\square \\
\square\end{array}$ & $4 / 9$ \\
\hline & 3 年生 存率 & $5 / 11$ & $1 / 2$ & $6 / 13$ \\
\hline
\end{tabular}

$\square: 3$ 年後生存 $\square: 3$ 年以内死亡

表 9 臨床病期と 3 生率

\begin{tabular}{|c|c|c|}
\hline I A & $\square \square \square \square \square \square$ & $2 / 6$ \\
\hline I B & $\square \mathbf{\square}$ & $1 / 2$ \\
\hline II $\mathrm{A}$ & $\square \square \square \mathbf{\square}$ & $3 / 4$ \\
\hline III A & $\mathbf{\square}$ & $0 / 1$ \\
\hline IV & & - \\
\hline 計 & & $6 / 13(46.2 \%)$ \\
\hline
\end{tabular}

表10 初回治療と 3 生率

\begin{tabular}{|c|c|c|c|c|}
\hline 病期 & $R T$ & RT + Chemo. & Chemotherapy & 3生率 \\
\hline I & $\square$ & ㅁ口םघ & $\square$ & $3 / 8$ \\
\hline II & $\square$ & $\square \mathbf{\square}$ & $\square$ & $3 / 4$ \\
\hline III & & $\boldsymbol{\square}$ & & $0 / 1$ \\
\hline 計 & $2 / 3$ & $2 / 8$ & $2 / 2$ & $6 / 13$ \\
\hline
\end{tabular}

$\square: 3$ 年後生存

: 3 年以内死亡 
分類が用いられるが，流れは国際分類 (WF) の 有用性を評価する方向に向かっている ${ }^{6)}$. 今回 の我々の検討では, 主としてWFに従って病理 組織学的分類と腫瘍細胞表面マーカーを再検討 し，悪性度を決定した，その結果，鼻・副鼻腔 原発 MLは $\mathrm{T}$ 細胞性・高度悪性群に属する症例 を多くみた．本邦の報告を見て特徵的なととは， 西日本に向かうにつれて T 細胞型 MLの比率が 増えていること，そのためか東日本からは症例 報告は散見するすのの ${ }^{738)}$, 臨床統計処理を行な うほどのまとまった報告は鼻・副鼻腔 MLに関 してはほとんどないこと，である。非ホジキン $\mathrm{ML}$ 全体について屯同様に西日本に移るにつれ $\mathrm{T}$ 細胞型 $\mathrm{ML}$ の相対頻度が高いが99, その傾向 は成人のリンパ系腫瘍でのみ観察される傾向で あり, 成人 $\mathrm{T}$ 細胞白血病 $(\mathrm{ATL})$ の分布と一致 する(10). こういった疫学的な観点からみると, 鼻・副鼻腔 MLの中には ATL がかなり含まれ ている可能性が高いと考えられるが1112)，免疫 学的にはまだ証明されていない，われわれの症 例においても，1985年より HTLV-1 抗体值を 測定しているが，今のとてろ陽性者はいない.

鼻・副鼻腔原発 MLは，その臨床像の特徵之 して，局所制御が比較的良好にもかかわらず， 放射線照射範囲外の局所あるいは遠隔へ比較的 早期に転移を来たすことが知られている3゙. わ れわれの今回の検討でも同様の結果であり，3 年以内の早期に放射線照射範囲外の局所あるい は遠隔へ再発・転移をきたして死亡する場合が 多かった.

予後を左右する因子に関しては，Robbins ら13) が検討を行なっているが，それによれば病 巣の拡がり (TNM 分類におけるT因子) が予後 を左右している，我々の検討でも，腫瘍が鼻腔 に限局している場合は比較的予後がよく（3生 率 $=75.0 \%)$, 副鼻腔に病巣が及ぶ，あるいは存 在する場合は極めて予後不良であった（3生率 $=0 \%$ ).

症例の中には寛解に至らず，急激な転帰で死 亡するあのが見られたが，それらはいずれあ，
$\mathrm{T}$ 細胞型の MLであった。 このようなタイプの MLは peripheral nasal T-cell lymphoma と 呼ばれ, 藏器浸潤性が強く, 予後は不良とされ ている ${ }^{4)}$. 今回の我々の検討ではB 細胞型の症 例数が少ないために，細胞マーカーと予後との 間には，有意の相関を認めるには至らなかった が，山中ら ${ }^{4)}$ の報告のように， $\mathrm{T}$ 細胞型である ことは予後をより悪くせしめる因子と考えられ る.

このように不良な経過をしめす臨床像を考え ると, 鼻・副鼻腔 MLの初回治療の在り方を改 める必要があると考えられた ${ }^{1{ }^{1814}}$. 治療法に関 しては, 当科では1970年代の早期の症例をのぞ けば, 従来より放射線療法と化学療法 (VE MP, ないしVEPA 療法) を組み合わせた治療を行な っている. しかし，今回検討した症例では，化 学療法は 5 クール以内であり, その内容も現時 点から見ると, 比較的 mild なものであったと 判断せざるを得ない。前述のように, 臟器浸潤 性の高い peripheral nasal T-cell lymphoma が多い点，および早期に放射線照射範囲外の局 所あるいは遠隔へ再発・転移をきたして死亡す る症例が多い点を考えると, 今後は強力な化学 療法を主体とした治療を行ない，治療効果を高 める必要があると思われた．とのような観点か ら現在当科では化学療法として, 中等度悪性群 に対しては交互 VEPA 療法ないし CHOP 療 法を選択し，高度悪性群に対しては CHOP-B 療法, MACOP-B 療法ないしさらにVP-16を 組み合わせたものを選択している，今後，症例 を集積して，その効果について検討を行ないた い.

最後に, 腫瘍細胞マーカーの検討のために, 我々の用いた免疫染色について述べる。フォル マリン固定・パラフィン包埋組織材料を用いて 検索する時に使用可能な $\mathrm{T}, \mathrm{B}$ 細胞表面マーカ 一とその特異性・応用性については，表11に まとめた ${ }^{2)}$. T 細胞表面マーカーとしては, 現状 では UCHL-1 と MT-1 の併用が最も信頼 性が高いようである. T-cell lymphoma の中に 
は，B-cell antibody に染まるものがあるので， B-cell lineage を証明するには 2 種類以上の抗 体の陽性を示す方が良い，我々は，UCHL-1,
MT-1 および L-26 の免疫染色により $\mathrm{T} ， \mathrm{~B}$ 細 胞性を決定した ${ }^{15)}$.なお，乙れらの反応は必ず しもleucocyte specific とはいえないので, leuco-

表11 T, B 細胞マーカー（フォルマリン固定・パラフィン包埋材料）

\begin{tabular}{|c|c|c|}
\hline Mo Ab & 特 & 疾患（悪性リンパ腫）への応用 \\
\hline UCHL 1 & $\left.\begin{array}{l}\mathbf{T} \text { 細胞 } \\
\text { 顆粒球 } \\
\text { ある種の組織球 }\end{array}\right]$ の細胞膜を染める。 & $\begin{array}{l}\text { ・50〜86\%の T-細胞型リンパ腫で (+) } \\
\text { ・T-Lymphoblastic Lymphomaでは、 } \\
\text { MT 1 の方がよく染まるととあり } \\
\text { ・まれに、Bー細胞型リンパ腫で }(+)\end{array}$ \\
\hline MT 1 & $\begin{array}{l}\mathbf{T} \text { 細胞 Jの細胞膜を染める。 } \\
\text { 顆粒球 }\end{array}$ & 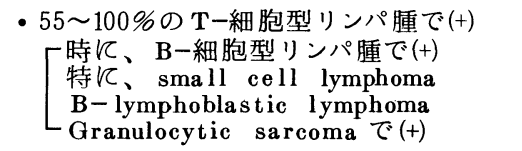 \\
\hline MT 2 & 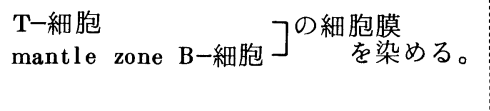 & 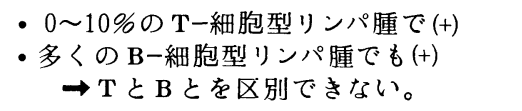 \\
\hline L 60 & $\begin{array}{l}\text { 正常組織では、Tー細胞を染色し、 } \\
\text { 多くのB-細胞は染色しない。 } \\
\text { しかし、Bー細胞型リンパ腫で(+) }\end{array}$ & $\begin{array}{l}\text { - Lymphoma では、 } \\
\text { TとB } \mathrm{T} \text { とを別できない。 }\end{array}$ \\
\hline \multicolumn{3}{|c|}{ 2. Bー細胞のマーカー } \\
\hline MB 1 & $\begin{array}{l}\text { B-細胞（形質細胞以外） } \\
50 \% \text { の成熟 } \mathbf{T} \text {-細胞 } \\
\text { の細胞膜を染める。 }\end{array}$ & $\begin{array}{l}\text { ・ B-細胞型リンパ腫 }(+) \\
\text { - CD 8+, CD } 30+\text { T-細胞型リンパ腫 }(+\end{array}$ \\
\hline MB 2 & B一細胞の細胞質を染める。 & $\begin{array}{l}\text { ・ } 90 \sim 100 \% \text { の T-細胞型リンパ腫で(+) } \\
\text { ・16〜 18\%の B-細胞型リンパ腫で(+) }\end{array}$ \\
\hline LN 1 & $\begin{array}{l}\text { germinal center Bーリンパ球の } \\
\text { 細胞膜ないし細胞質を染める。 }\end{array}$ & $\begin{array}{l}\text { ・B-細胞型リンパ腫で(+) } \\
\quad \text { ；フォルマリン固定で、50\%(+) } \\
\text { B 5 固定で、80\% (+) } \\
\text { ・まれに T-細胞型リンパ腫で(+) }\end{array}$ \\
\hline $\begin{array}{l}\mathrm{L} \mathrm{N} 2 \\
\quad=\mathrm{MB} 3\end{array}$ & $\begin{array}{l}\text { B-リンパ球 } \\
\text { germinal center及びmantle zone) } \\
\text { interdigitating reticulum cell } \\
\text { の核膜を染める。 }\end{array}$ & $\begin{array}{l}\text { ・B-細胞型リンパ腫で(+) } \\
\quad \text {; フォルマリン固定で、50\%(+) } \\
\text { B5 固定で、90\%(+) } \\
\text { ・ HLA-DR (+) 細胞に反応し、 } \\
\text { Tー細胞型リンパ腫でも(+)の可能性 } \\
\quad \text {; B-細胞の特異的マーカーではなし } \\
\text { ・ Reed-Sternberg 細胞 (+) }\end{array}$ \\
\hline $\mathrm{K}$ i B 3 & $\begin{array}{l}\text { Bーリンパ球 } \\
\text { (germinal center及びmantle zone) } \\
\text { 形質細胞、単球（まれ） }\end{array}$ & 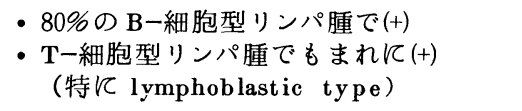 \\
\hline L 26 & B一細胞 & $\begin{array}{l}\text { ・85\%のB-細胞型リンパ腫で(+) } \\
\text { ・T一細胞型リンパ腫ででくまれに(+) } \\
\text { ・Reed-Sternberg 細胞で }(+)\end{array}$ \\
\hline $4 \mathrm{~KB} 5$ & B一細胞 & $\begin{aligned} & \text { ・ } 88 \sim 100 \% \text { B-細胞型リンパ腫で(+) } \\
& \text { ・しばしば T-細胞型リンパ腫で(+) } \\
& \text { （特に T-lymphoblastic type） }\end{aligned}$ \\
\hline
\end{tabular}

$\mathrm{MoAb}$; モノクローナル抗体 
cyte common antigen ないし cytokeratin の免 疫染色にて leucocyte の疾患であるととを確認 するととが必要である ${ }^{15)}$. 鼻・副鼻腔 MLにお ける腫瘍細胞マーカーの検討は，まだ充分にな されていないが，全国的に鼻・副鼻腔 MLの再 検討が望まれている現在 ${ }^{16)}$, review 組織診断の 際に上述の方法で腫瘍細胞表面マーカーを検索 すれば，更に多くの情報がMLについて得られ るあのと思われる。

$$
\text { まとめ }
$$

1975年より1988年の間に当科において，初回 治療を行なった，鼻・副鼻腔 MLの16症例につ いて検討した.

予後に影響を与えた因子としては，今回の検 討では, 病巣が副鼻腔に存在するか否かであり, 副鼻腔に病巣が存在する症例は非常に予後不良 であった。

治療法に 関しては，1970 年代の早期の症例 をのぞけば，従来より放射線療法と化学療法 (VEMP, VEPA) を組み合わせた治療を行なっ ているが，早期の遠隔転移や RT 照射範囲外局 所再発の起こる点, さらには病理組織型の悪性 度を考えれば，さらに強力な化学療法の導入を 行なう必要がある，と考えられた。

\section{文 献}

1）河野嘉彦, 夜陣紘治, 世良公志, 他: 当科におけ る頭頸部悪性リンパ腫の 統計的観察. 耳鼻臨床 補 $27: 237 \sim 247,1988$.

2) Chan JKC, Ng CS and Hui PK : A simple guide to the terminology and application of leucocyte monoclonal antibodies. Histopathology $12: 461 \sim 480,1988$.

3 ）猪川 勉, 草場雅子, 増山敬祐, 他 : 両側性に発 生した鼻腔原発の悪性リンパ腫症例. 耳鼻 34 ： 1178 1181, 1988.

4) 山中 昇, 形浦昭克, 砂川秀充, 他 : 鼻性 $\mathrm{T}$ 細胞
型リンパ腫の臨床病理組織学的検索一進行性鼻壊 瘟の本態の解明一. 耳喉 $53:$ 1075 1086, 1981.

5 ）川出博彦, 瀧本 勲, 稲福 繁, 他 : 興味ある鼻 malignant lymphoma 症例. 耳喉 $57: 333 \sim 339$, 1985.

6 ) 丹下 剛 : 非ホジキンリンパ腫の形態学的分類. Modern Phisician 9 : 149 151, 1989.

7) 松本順雄, 杉原洋行, 斎藤 等, 他: 免疫組織化 学で確診し得た鼻腔内悪性リンパ腫の一例. 耳鼻 臨床 補 $25 ： 78 \sim 85,1988$.

8 ）山中 昇, 形浦昭克, 小笠原実 : サプレッサー活 性を呈した鼻性 T細胞型リンパ腫．耳喉 $55 ： 333$ 〜39, 1983.

9 ) 花岡正男: 成人 $\mathrm{T}$ 細胞白血病の病理一びまん性リ ンパ腫, NP 亜型一. Oncologia $4: 22 \sim 29,1983$.

10）田島和雄 : 成人非ホジキンリンパ腫の疫学. Modern Phisician 9 : 133 136, 1989.

11）武田直弘, 武田典子, 小笠原寛, 他 : 鼻腔原発成 人 $\mathrm{T}$ 細胞白血病・リンパ腫. 耳鼻臨床 $82: 657$ 664, 1989.

12）稲木匠子, 近森義則, 丘村 熙: 副鼻腔腫瘍とし ての成人 $\mathrm{T}$ 細胞白血病・リンパ腫の 1 例. 日耳鼻 $88: 1567 \sim 1572,1985$.

13) Robbins KT, Fuller LM, Vlasak M, et al : Primary lymphoma of the nasal cavity and paranasal sinuses. Cancer $56: 814 \sim 819,1985$.

14）大屋耕子, 伊藤 衛, 西田 功, 他: 診断に苦慮 した鼻腔原発末梢性 $\mathrm{T}$ 細胞リンパ腫の 1 例. 広島 医学 42 : 298 301, 1989.

15）原田康夫, 平川勝洋, 永澤 昌, 他: 鼻腔原発末 梢性 $\mathrm{T}$ 細胞型悪性リンパ腫の 1 例. 耳喉頭頸 61： 1041 1047, 1989.

16）形浦昭克，鈴木敏夫，原淵保明，他：進行性鼻壊 疽の 1 例. 耳喉頭頸 $61 ： 748 \sim 754,1989$.

$\left.\begin{array}{l}\text { 原稿受付 : 平成 } 2 \text { 年 } 3 \text { 月 } 22 \text { 日 } \\ \text { 原稿採択 : 平成 } 2 \text { 年 } 4 \text { 月 } 19 \text { 日 } \\ \text { 別刷請求先 : 有重秀三 } \\ \text { 干734 広島市南区霞1-2-3 } \\ \text { 広島大学医学部耳鼻咽喉科学教室 }\end{array}\right)$

